\title{
Prólogo. El poder de la economía en el Siglo de Oro

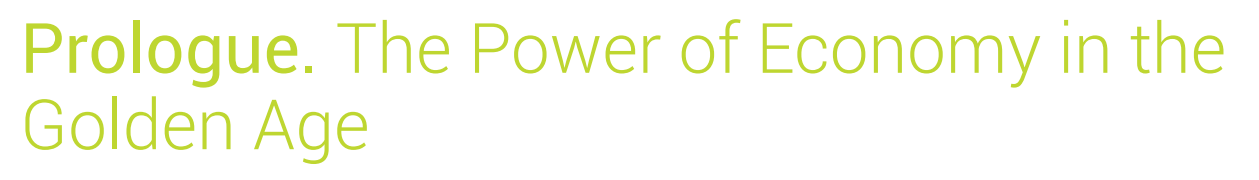

\section{Christoph Strosetzki}

Universität Münster

ALEMANIA

stroset@uni-muenster.de

[Hipogrifo, (issn: 2328-1308), Volumen extraordinario, 1, 2018, pp. 177-178]

DOl: http://dx.doi.org/10.13035/H.2018.extra01.12

Con el mercantilismo el mercader se convirtió en la figura central de la sociedad. Si a partir de entonces los nobles aspiraron a ejercer el oficio de mercader, vuelto prestigioso gracias a la riqueza que conllevaba, no dejaba de ser evidente, en caso de injuria, la desigualdad existente entre el honor del noble y aquel del mercader; en efecto, ya desde los tiempos bíblicos el usurero y el logrero dañaron la imagen de este último. Cierto es que el comerciante se encuentra bajo la sospecha de ser codicioso, de sacar provecho del trabajo ajeno y de vivir ociosamente en desmedro del trabajo productivo. Sin embargo, no deja de situarse en las antípodas tanto del caballero ocioso, al cual se le prohíbe trabajar, como del pobre, quien gana su dinero a través de la mendicidad y no del trabajo. De ello surgen preguntas como las siguientes: ¿En qué consiste el iustum pretium del trabajo mercantil? ¿Qué ámbitos de conocimiento, aparte de aritmética y geografía, tiene que dominar el mercader? ¿Debe actuar según la moral, o tan sólo simular hacerlo, para así poder hacer frente al engaño ajeno de manera más eficiente? La tratadística y la literatura ficcional otorgan respuestas que permiten formarse una idea de los comienzos del capitalismo. ¿Cómo se llegó de la prohibición del cobro de intereses a la marginalización de todo el estamento mercantil? Si a partir de la riqueza del mercader se obtenía un alto prestigio social, lo cual llevó también a los nobles a ejercer el oficio de comerciante, ¿por qué entonces los mercaderes ricos aspiraban a un título de nobleza?

Algunos de los artículos reunidos en esta sección monográfica tratan del papel de los judeoconversos portugueses, de las ideas económicas en textos del Inca Garcilaso de la Vega, de los mercaderes en las jácaras de Quevedo, de las «orientalia» desde el punto de vista de los jesuitas portugueses, y también del rol del mercader en el conjunto del teatro del Siglo de Oro y también en Ruiz de Alarcón. 
Se ocupan así mismo de la transformación de la valoración del comerciante desde la patrística medieval al mercantilismo francés y de la pregunta de si las mujeres viudas no son mejores comerciantes que sus maridos.

Las contribuciones del presente apartado se remontan en su mayoría al Congreso Internacional «El poder de la economía: la imagen de los mercaderes y el comercio en el mundo hispánico de los siglos XVI y XVII», coorganizado por GRISO-Universidad de Navarra y la Gallerie degli Uffizi, que tuvo lugar en Florencia, en la Gallerie degli Uffizi, del 9 al 10 de febrero de 2017. Se agradece a la DFG por el financiamiento de la edición.

\section{DFG}

